\title{
Transcriptional profiling of host gene expression in chicken embryo lung cells infected with laryngotracheitis virus
}

\author{
Jeong Yoon Lee ${ }^{1,2}$, Joon Jin Song ${ }^{2,3}$, Ann Wooming ${ }^{1}$, Xianyao Li ${ }^{4}$, Huaijun Zhou ${ }^{4}$, Walter G Bottje ${ }^{1,2}$,
} Byung-Whi Kong ${ }^{1,2^{*}}$

\begin{abstract}
Background: Infection by infectious laryngotracheitis virus (ILTV; gallid herpesvirus 1) causes acute respiratory diseases in chickens often with high mortality. To better understand host-ILTV interactions at the host transcriptional level, a microarray analysis was performed using $4 \times 44 \mathrm{~K}$ Agilent chicken custom oligo microarrays.

Results: Microarrays were hybridized using the two color hybridization method with total RNA extracted from ILTV infected chicken embryo lung cells at 0, 1, 3, 5, and 7 days post infection (dpi). Results showed that 789 genes were differentially expressed in response to ILTV infection that include genes involved in the immune system (cytokines, chemokines, MHC, and NF- $\kappa$ B), cell cycle regulation (cyclin B2, CDK1, and CKI3), matrix metalloproteinases (MMPs) and cellular metabolism. Differential expression for 20 out of 789 genes were confirmed by quantitative reverse transcription-PCR (qRT-PCR). A bioinformatics tool (Ingenuity Pathway Analysis) used to analyze biological functions and pathways on the group of 789 differentially expressed genes revealed that 21 possible gene networks with intermolecular connections among 275 functionally identified genes. These 275 genes were classified into a number of functional groups that included cancer, genetic disorder, cellular growth and proliferation, and cell death.
\end{abstract}

Conclusion: The results of this study provide comprehensive knowledge on global gene expression, and biological functionalities of differentially expressed genes in chicken embryo lung cells in response to ILTV infections.

\section{Background}

Infectious laryngotracheitis virus (ILTV; gallid herpesvirus 1) is the only member of the Iltovirus genus of the Alphaherpesvirinae subfamily of the Herpesviridae family. ILTV includes $\sim 150 \mathrm{~kb}$ of linear dsDNA genome consisting of two unique regions (unique long; UL and unique short; US), inverted repeats (IR) and terminal repeats (TR) flanking the US region [1]. About 76 open reading frames (ORFs) have been shown to express viral proteins in ILTV [2]. The genome structure and gene contents of the ILTV genome clearly prove its classification as an alphaherpesvirus [3]. Infection of ILTV causes an upper respiratory disease in chickens during lytic infection, and ILTV can establish latency in the central nervous system.

\footnotetext{
* Correspondence: bkong@uark.edu
'Department of Poultry Science, University of Arkansas, Fayetteville, AR

* Correspondence: bkong@uark.edu
'Department of Poultry Science, University of Arkansas, Fayetteville, AR 72701, USA
} 72701, USA

Respiratory symptoms of ILTV infection include dramatically increased mucus formation in the trachea and tracheal hemorrhage that can cause up to $70 \%$ mortality. Currently, live attenuated vaccines developed from chicken embryo or cultured cells are commercially available to control ILTV disease [4]. However, vaccinal laryngtracheitis (VLT), resulting from reversion of vaccine virus to virulent form and spreading from vaccinated- to unvaccinated birds, is often associated with the use of live attenuated ILTV vaccines $[5,6]$.

Microarray methodology was developed as an epochal method to simultaneously analyze enormous data sets for gene expression patterns in various biological conditions [7]. Microarrays have been used to investigate host responses to the infection of various viruses such as Epstein-Barr virus (EBV) [8-10], varicella-zoster virus (VZV) [11], human cytomegalovirus (HCMV) [12], Marek's disease virus (MDV) [13-17], herpesvirus of turkey 
[18], herpes simplex virus-1 (HSV-1) [19,20], hepatitis virus [21], human immunodeficiency virus (HIV) [22-25] and coxsackieviruses [26].

Microarray data sets can be interpreted further by clustering analysis. Many of the heuristic clustering methods have several shortcomings; these include the determination of the number of clusters which generally is unknown when there is no prior knowledge of the number or there no other information about the structure of the data to be clustered. A model-based clustering method can overcome these critical drawbacks by treating a clustering problem as a model selection problem over a variety of candidate models specified by different numbers of clusters and distribution, and by estimating the number of clusters in the clustering analysis. The best model is selected on the basis of a model selection criterion, simultaneously providing the optimal number of clusters and assigning cluster membership to observations.

To our knowledge, the effects of ILTV infection on changes in global gene expression in host cells have not been previously reported. ILTV is a special type of herpesvirus that causes acute respiratory disease in poultry. Thus, the objective of this study was to understand host responses to ILTV infection in cultured chicken embryo lung cells using microarray analysis. The microarray used in the current study contains $44 \mathrm{~K}$ chicken genes including functionally identified genes, predicted ORFs, ESTs, genomic contigs, chicken microRNAs and various control spots [27]. Importantly, functional analysis of differentially expressed genes should follow gene discovery research. To this end, a software program (Ingenuity Pathway Analysis), specifically developed to analyze large data sets such as microarray data for biological functionalities, gene networks, and physiological pathways [28], was used to assign biological functionalities and molecular interactions in chicken embryo lung cells after 1 to 7 days in response to ILTV infection.

\section{Results and Discussion}

\section{Gene expression profile of lung cells infected by ILTV}

Primary chicken embryo lung cells at passage 1 were infected by the USDA reference strain of ILTV and cells were collected at 1, 3, 5, and $7 \mathrm{dpi}$. Cytopathic effects (CPE) were observed by $3 \mathrm{dpi}$, which became more severe by 5 dpi. Massive cell disruption was observed at 7 dpi (Figure 1). Total RNA was isolated from both controls and infected lung cells at each dpi time point and subjected to microarray analysis.

To control for dye bias effects, spike-in control mixtures were utilized by mixing with RNA samples according to the manufacturer's recommendations (See Methods). The spike-in RNA controls consisted of two sets of synthetic RNA mixtures derived from the
Adenovirus E1A genes with different concentrations in each set [29]. The Agilent chicken $4 \times 44 \mathrm{~K}$ oligo gene expression array contains 320 spike-in indicator spots to be hybridized with spike-in controls of both A mix, which was hybridized with $\mathrm{Cy} 3$, and the B mix hybridized with Cy 5 on each array. These spike-in sets were mixed with either uninfected control or infected samples and co-hybridized to arrays. The ratio of signal intensities for all spike-in spots were calculated, evaluated, and revealed no significant dye effects on all array slides (data not shown) as reported previously [29]. All raw and normalized data were deposited in the Gene Expression Omnibus (GEO; accession number: GSE20630).

Normalized signal intensities were subjected to statistical analysis to find differentially expressed genes during ILTV infection in cultured embryonic lung cells. The $44 \mathrm{~K}$ array revealed 11,491 genes with significant signal intensities that were sorted by signal to noise ratio $(\mathrm{SNR})>3$, meaning that real (forward) signals of the samples were three times greater than background signals. In order to discover time course change in gene expression patterns, a model-based method [30] was used for clustering the gene expression profiles. A key drawback in heuristic clustering techniques is that it is difficult to determine the number of clusters a priori. The method enables the number of clusters to be determined by estimating the number of components in a multivariate normal mixture model from which the data are generated. The clustering analysis resulted in three gene groups (Figure 2). Group 1 included a total of 789 genes that showed significant differential expression in response to ILTV, Group 2 included 6,265 genes that displayed moderate alterations, and Group 3 included 4,437 genes that revealed no alterations during ILTV infection at four time points in chicken lung cells. Of the 789 genes in Group 1 exhibiting differential expression in response to ILTV (see Additional file 1), the top $10 \%$ (79 genes) were sorted by statistical analysis based on the highest value of standard deviations using the mean values of four different time points (Table 1). This approach highlights genes with more significant alterations in response to ILTV overtime. Out of the 789 genes, 390, 370, 320, and 422 genes were down-regulated, while 399, 419, 469, and 367 genes were up-regulated relative to uninfected cells at $1,3,5$, and $7 \mathrm{dpi}$, respectively.

\section{Quantitative reverse transcription-PCR (qRT-PCR)}

To validate the microarray data, 20 genes were subjected to qRT-PCR using gene specific primer pairs and the same RNA samples as in the microarray analysis (Table 2). Results were analyzed by $2^{-\Delta \Delta C t}$ method to determine relative levels of gene expression at each dpi time point compared to uninfected control [31]. There were no differences 


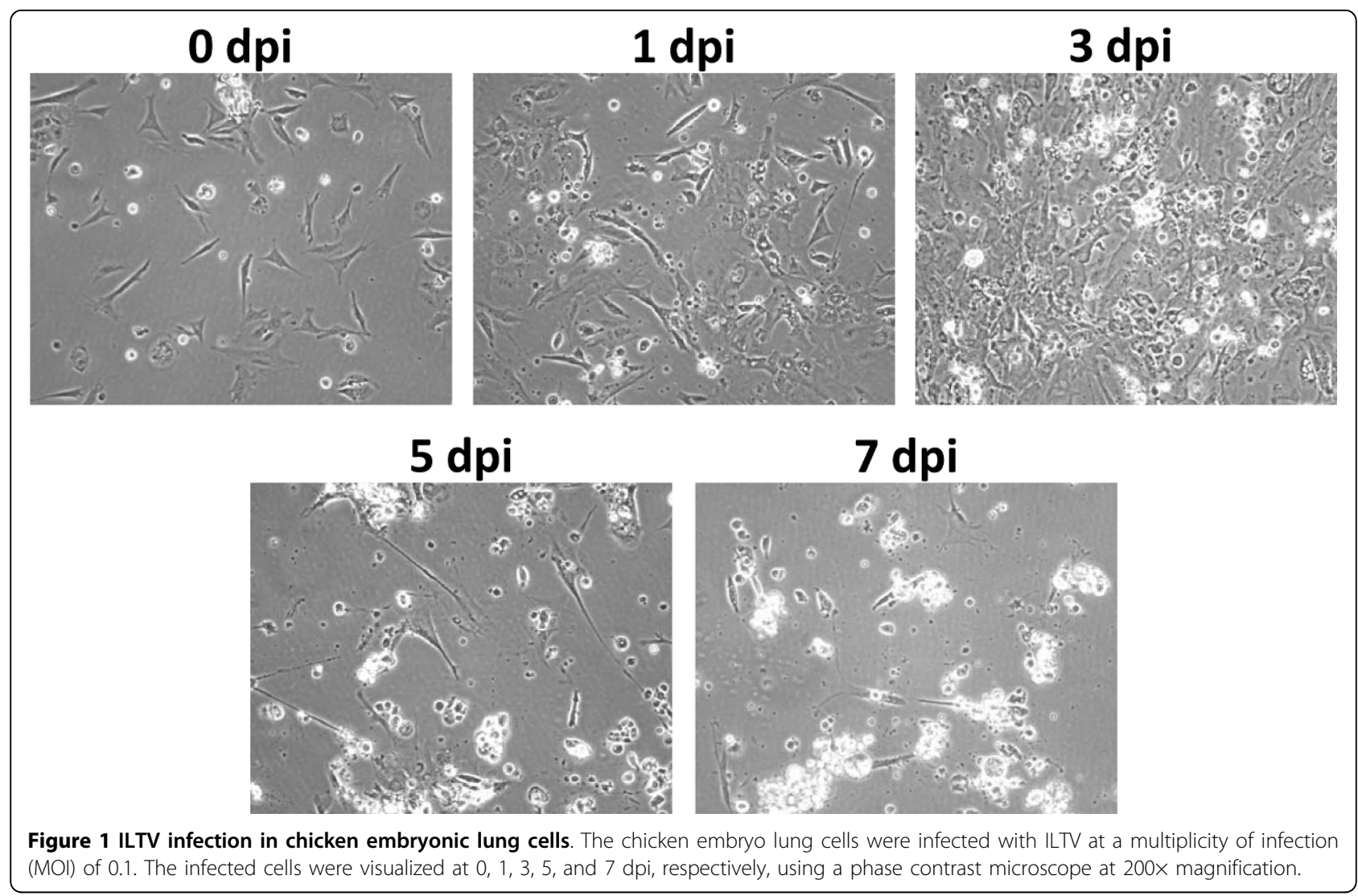

between microarray data and the qRT-PCR at any dpi time point (Table 3). However, it should be noted that fold change values for certain genes obtained by qRT-PCR analysis showed much greater expression levels than those observed in the microarray analysis. For example, the fold changes for the gene expression of matrix metalloproteinase (MMP) 27, interleukin (IL) 6, fatty acid binding protein (FABP) 4, IL8, and CXC chemokine $\mathrm{K} 60$ at 3- or 5 dpi showed much higher levels in qRT-PCR analysis compared to fold changes shown in microarray analysis (Table 3). Possibly, this qualitative difference between methodologies may be attributed to the upper detection limits of the fluorescent intensities for the array scanner. Based on quality control measures, such as the spike-in controls and the results of targeted qRT-PCR indicate that the microarray data sets for differential gene expression are valid to investigate genome-wide differential expression patterns for host responses during ILTV infection.

\section{Expression clustering}

The pattern of differential gene expression over time can provide insights into biologically functional relevance among genes. In the present study, a model-based clustering method [30] was used to cluster alteration patterns for the 789 differentially expressed genes in response to ILTV infection and revealed 7 gene clusters exhibiting distinct expression patterns (Figure 3 and Additional file 2). The 287 genes placed in cluster (C) 1 showed only nominal increases at 3 and $5 \mathrm{dpi}$ followed by decreased expression levels at $7 \mathrm{dpi}$ that were similar to those at the onset of the experiment. The $\mathrm{C} 2$ representing 97 genes exhibited a dramatic increase in gene expression only at $7 \mathrm{dpi}$, whereas the expression levels of the 90 genes in C3 progressively declined at 5 and 7 dpi. Three genes in $\mathrm{C} 4$ showed higher expression during early infection ( $1 \mathrm{dpi})$, sharp increases at 3 and $5 \mathrm{dpi}$, followed by a slight decline at $7 \mathrm{dpi}$. Expression patterns of 9 genes in C5 showed slightly lower expression at 1 dpi relative to the other time points, a dramatically increase at 3 and $5 \mathrm{dpi}$, followed by decreased expression at $7 \mathrm{dpi}$. The 85 genes in $\mathrm{C} 6$ showed lower expression at $1 \mathrm{dpi}$ followed by a progressive increase during the later time points, which was opposite to 218 genes in $\mathrm{C} 7$ that showed higher expression at $1 \mathrm{dpi}$ followed by decreased expression at 3, 5, and $7 \mathrm{dpi}$. GenBank accession numbers for genes in each cluster are shown in the Additional file 2.

Interestingly, the genes in $\mathrm{C} 4$ that exhibited the highest expression during ILTV infection include cytokines (IL8 and IL1 $\beta$ ) and a chemokine (CXC-K60), while in the C5, IL6 was most highly expressed. From these findings, it is reasonable to hypothesize that expression of 
A

Group 1 - Higher variation (789 genes)

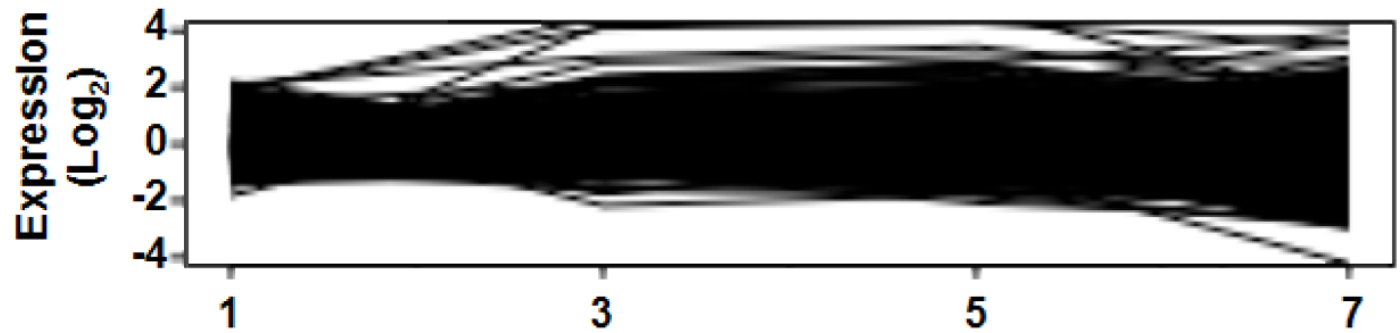

Days post infection

B

Group 2 - Moderate variation (6265 genes)

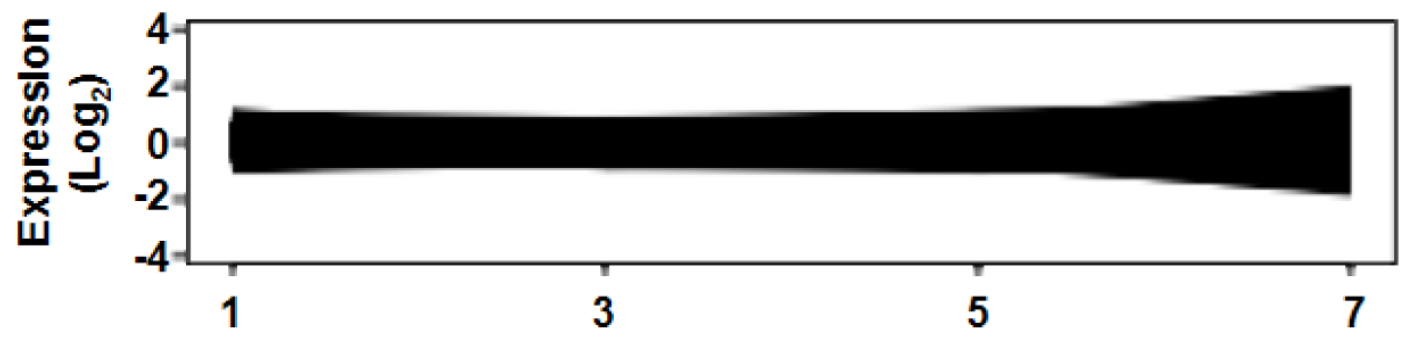

Days post infection

C

Group 3 - No variation (4437 genes)

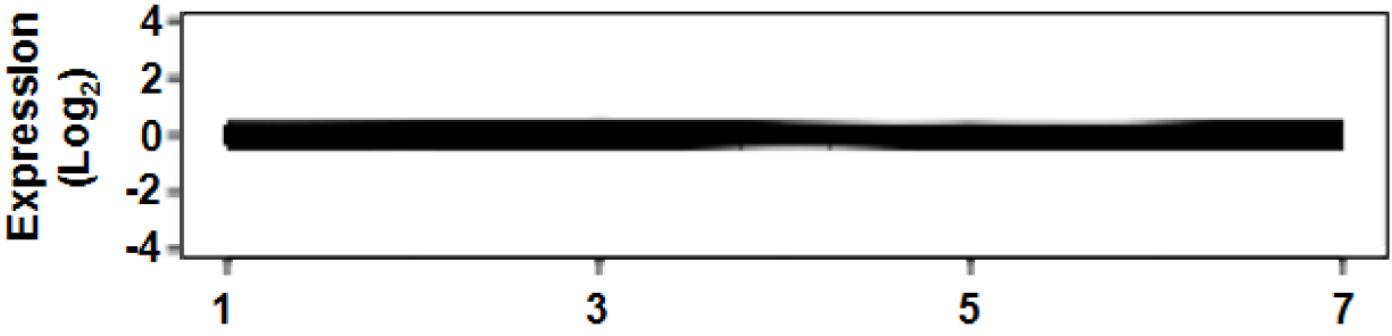

Days post infection

Figure 2 Groups for sorting differentially expressed genes in the time course of ILTV infection. The 11,491 genes showing a signal to noise ratio $(S N R)>3$ were sorted into three groups based on alterations of fold changes at each dpi time point. The Y-axis represents log 2 values of fold changes and the $X$-axis indicates $d p i$ time points.

functionally relevant genes such as cytokines and chemokines released in response to an immune challenge may be regulated similarly during a specific immunological challenge.

\section{Functional Gene Ontology (GO)}

Recently, new bioinformatics tools have been developed to facilitate efficient analysis of biological functionalities for large numbers of differentially expressed genes obtained from microarray analysis. By using the IPA program (http://www.ingenuity.com/), bioinformatics aspects of differentially expressed genes during ILTV infection were analyzed for the relevance of gene functionalities and gene networks. While 789 differentially expressed genes were used as the input number of genes, only 275 have been characterized with specific cellular functions according to the IPA program. Results obtained with the IPA program in terms of numbers of genes, biological functions of genes and categories were independently confirmed with a second bioinformatics 
Table 1 Top 10\% (79 out of 789 genes) of the most highly differentially expressed

\begin{tabular}{|c|c|c|c|c|c|}
\hline \multirow{2}{*}{$\begin{array}{l}\text { Accession } \\
\quad \#\end{array}$} & \multirow[t]{2}{*}{ Gene Symbol } & \multicolumn{4}{|c|}{ Fold Change } \\
\hline & & $\begin{array}{c}\text { Day } \\
1\end{array}$ & $\begin{array}{c}\text { Day } \\
3\end{array}$ & $\begin{array}{l}\text { Day } \\
5\end{array}$ & $\begin{array}{c}\text { Day } \\
7\end{array}$ \\
\hline Y14971 & CXC chemokine K60 & 3.7 & 17.3 & 19.7 & 11.3 \\
\hline X65459 & FABP7 & 1.1 & 0.3 & 0.8 & 0.2 \\
\hline X16881 & $\mathrm{CDC2}$ & 1.9 & 0.4 & 0.7 & 0.4 \\
\hline X03509 & CKB & 0.9 & 4.7 & 5.5 & 2.0 \\
\hline X02009 & LTF & 0.7 & 2.7 & 3.6 & 3.2 \\
\hline U62026 & CENPF & 3.3 & 0.7 & 1.4 & 0.6 \\
\hline U12438 & RFC2 & 1.9 & 0.8 & 1.0 & 0.3 \\
\hline U09350 & VIP & 2.0 & 0.2 & 0.3 & 0.2 \\
\hline M16199 & IL8 & 3.7 & 22.4 & 26.8 & 18.5 \\
\hline CR733296 & LIPG & 1.0 & 0.7 & 0.6 & 0.1 \\
\hline CR523746 & TMEM196 & 1.0 & 2.3 & 2.8 & 0.7 \\
\hline CR406543 & SELO & 1.0 & 0.9 & 1.1 & 4.1 \\
\hline CR406252 & $\begin{array}{l}\text { Prematurely terminated mRNA } \\
\text { decay factor-like }\end{array}$ & 1.2 & 1.1 & 1.4 & 4.7 \\
\hline CR391404 & ITGA8 & 0.7 & 0.8 & 0.5 & 0.2 \\
\hline CR391234 & LL & 1.5 & 0.3 & 0.6 & 0.2 \\
\hline CR387914 & CHAD & 1.1 & 0.8 & 0.7 & 0.2 \\
\hline CR385491 & $|\mathrm{D}| 1$ & 1.3 & 0.8 & 0.9 & 0.2 \\
\hline CR385166 & MYCN & 0.6 & 1.0 & 1.1 & 5.7 \\
\hline CR385124 & DHCR7 & 1.3 & 0.9 & 1.0 & 0.3 \\
\hline CR382435 & HDGFRP3 & 0.8 & 0.9 & 0.9 & 5.1 \\
\hline CR352395 & OSTN & 0.8 & 0.9 & 0.9 & 4.2 \\
\hline CO635775 & HSP90AA1 & 0.8 & 0.5 & 0.5 & 2.6 \\
\hline CN218923.1 & ARHGEF9 & 1.1 & 1.3 & 0.9 & 5.5 \\
\hline CF250950 & ALDH1A3 & 0.6 & 2.1 & 2.3 & 3.6 \\
\hline CD763113 & FDPS & 1.1 & 0.6 & 0.7 & 0.2 \\
\hline BX936026 & AURKA & 2.4 & 0.5 & 0.7 & 1.0 \\
\hline BX935864 & XBP1 & 0.9 & 0.8 & 0.7 & 3.4 \\
\hline BX935550 & AKR1D1 & 0.6 & 2.9 & 2.7 & 1.2 \\
\hline BX935026 & MAT1A & 0.7 & 1.0 & 0.7 & 3.5 \\
\hline BX934121 & TFPI2 & 0.9 & 1.5 & 2.2 & 5.5 \\
\hline BX932212 & PTTG1 & 2.1 & 0.7 & 0.8 & 0.3 \\
\hline BX931971 & SPON2 & 1.6 & 2.8 & 4.0 & 12.1 \\
\hline BX931663 & ROPN1L & 0.7 & 2.7 & 1.1 & 5.6 \\
\hline BU456021 & SNAl1 & 1.9 & 1.0 & 0.7 & 0.4 \\
\hline BU409770 & HMG_COA_S & 2.5 & 1.4 & 1.2 & 0.3 \\
\hline BU200000 & TNFAIP6 & 1.0 & 1.9 & 4.0 & 0.4 \\
\hline BU138507 & CYP51 & 1.0 & 0.7 & 0.7 & 0.2 \\
\hline AJ851480 & ACSL1 & 1.2 & 7.3 & 8.7 & 7.3 \\
\hline AJ721110 & VNN2 & 0.5 & 3.3 & 6.5 & 2.5 \\
\hline AJ721107 & SLA & 0.8 & 1.1 & 1.4 & 5.0 \\
\hline AJ720861 & LSS & 1.3 & 1.1 & 1.3 & 0.2 \\
\hline AJ720657 & DNAJB9 & 0.9 & 0.9 & 0.8 & 3.8 \\
\hline AJ720217 & STARD4 & 1.8 & 0.9 & 1.0 & 0.3 \\
\hline AJ719858 & |TFG1 & 1.3 & 1.0 & 1.2 & 4.8 \\
\hline AJ719718 & SC4MOL & 1.1 & 0.8 & 1.1 & 0.2 \\
\hline AJ719295 & INSIG1 & 1.5 & 0.9 & 0.9 & 0.2 \\
\hline AJ443395 & TRIP13 & 2.1 & 0.6 & 0.7 & 0.4 \\
\hline
\end{tabular}

Table 1 Top $10 \%$ (79 out of 789 genes) of the most highly differentially expressed (Continued)

\begin{tabular}{|c|c|c|c|c|c|}
\hline AJ393939 & ITPR3 & 1.5 & 1.4 & 1.8 & 0.4 \\
\hline AJ309540 & IL6 & 0.9 & 4.8 & 7.2 & 3.1 \\
\hline AJ004940 & HSPA8 & 0.9 & 0.5 & 0.6 & 2.7 \\
\hline AF432506 & FABP4 & 1.0 & 5.3 & 7.1 & 14.9 \\
\hline AF411083 & SFTPA1 & 1.7 & 0.4 & 0.9 & 0.4 \\
\hline AF070478 & MMP-13 & 0.7 & 3.4 & 2.9 & 0.7 \\
\hline AF062392 & MMP27 & 0.8 & 4.1 & 6.6 & 3.5 \\
\hline AB031398 & LEFTY2 & 1.2 & 1.7 & 1.8 & 5.8 \\
\hline BU306841 & NSDHL & 1.5 & 0.6 & 0.8 & 0.1 \\
\hline BU144940 & ATF3 & 0.6 & 0.9 & 2.0 & 3.2 \\
\hline BU106686 & MKI67 & 2.6 & 0.8 & 1.1 & 0.5 \\
\hline BU336892 & $\mathrm{HSPH} 1$ & 1.0 & 0.5 & 0.5 & 3.2 \\
\hline CR385186 & PREDICTED: similar to CUG2 & 2.2 & 0.5 & 0.8 & 0.4 \\
\hline CR387761 & $\begin{array}{l}\text { PREDICTED: similar to Gap } \\
\text { junction alpha-7 protein }\end{array}$ & 1.2 & 0.7 & 0.8 & 0.2 \\
\hline BU456843 & $\begin{array}{l}\text { PREDICTED: similar to Cancer } \\
\text { susceptibility candidate } 5\end{array}$ & 2.9 & 0.7 & 1.2 & 0.6 \\
\hline BU468099 & $\begin{array}{l}\text { PREDICTED: similar to Histone } \\
\text { protein Hist } 2 \mathrm{~h} 3 \mathrm{cl}\end{array}$ & 2.5 & 0.9 & 0.9 & 0.4 \\
\hline BX950657 & $\begin{array}{l}\text { PREDICTED: chemokine (C-C } \\
\text { motif) receptor-like } 1 \text { isoform } 1\end{array}$ & 1.1 & 1.3 & 2.5 & 0.3 \\
\hline CR390562 & $\begin{array}{l}\text { PREDICTED: hypothetical } \\
\text { protein }\end{array}$ & 1.2 & 1.2 & 1.3 & 6.2 \\
\hline CR388632 & Unknown & 0.7 & 1.4 & 0.8 & 0.2 \\
\hline BU212825 & Unknown & 0.7 & 0.6 & 0.6 & 0.2 \\
\hline BU281664 & Unknown & 1.1 & 0.8 & 0.9 & 0.2 \\
\hline BU377399 & Unknown & 0.9 & 1.4 & 1.2 & 5.3 \\
\hline BU420694 & Unknown & 0.6 & 18.2 & 26.2 & 3.1 \\
\hline BU433279 & Unknown & 0.7 & 1.2 & 2.4 & 3.5 \\
\hline CR385201 & Unknown & 0.6 & 5.0 & 7.0 & 0.6 \\
\hline CR385678 & Unknown & 1.1 & 1.3 & 1.8 & 5.5 \\
\hline CR386845 & Unknown & 1.0 & 0.8 & 0.7 & 3.1 \\
\hline CR389767 & Unknown & 1.2 & 3.2 & 3.2 & 0.5 \\
\hline CR389813 & Unknown & 1.0 & 1.3 & 1.2 & 5.9 \\
\hline CR390519 & Unknown & 1.4 & 1.5 & 1.8 & 8.3 \\
\hline CR391100 & Unknown & 0.3 & 3.0 & 4.1 & 0.4 \\
\hline DR431104 & Unknown & 1.2 & 1.7 & 1.9 & 0.3 \\
\hline
\end{tabular}

The highly differentially expressed genes were sorted. All genes were matched and verified with UniGene function of NCBI database.

tool, DAVID (Database for Annotation, Visualization and Integrated Discovery) version 6.7 (http://david.abcc. ncifcrf.gov/) (data not shown). The group of 275 differentially expressed genes was placed into 65 functional groups (see Additional file 3) and the top 25 functional groups of genes are displayed in Figure 4. The main categories for gene functionalities include diseases and disorders, molecular and cellular functions, and physiological system development. Gene information was repeatedly used in multiple groups of functionalities due to the multi-functional characteristics for designated genes. It can be seen that the cancer related function 
Table 2 Primers used for qRT-PCR

\begin{tabular}{|c|c|c|}
\hline Accession \# & $\begin{array}{l}\text { Forward Primer } \\
\text { Reverse Primer }\end{array}$ & Gene Symbol \\
\hline \multirow[t]{2}{*}{ AJ711110 } & TGGTGGCTCGTTACCACAAG & VNN2 \\
\hline & TTCCCAAAGGGAGTCTCGAA & \\
\hline \multirow[t]{2}{*}{ AF070478 } & TCCCAAAACGCCAGAGAAAT & MMP-13 \\
\hline & TCGCCAGAAAAACCTGTCCT & \\
\hline \multirow[t]{2}{*}{ AF062392 } & CAGCCCCAGTGAATTTCCTC & MMP27 \\
\hline & GACGGTTGGCCTITTACCTG & \\
\hline \multirow[t]{2}{*}{ X03509 } & CCAGGGGTATCTGGCACAAT & CKB \\
\hline & TCATGTTGCCACCTTTCTGC & \\
\hline \multirow[t]{2}{*}{ AJ309540 } & CCTGTTCGCCTITCAGACCT & IL6 \\
\hline & GCCAGGTGCTITGTGCTGTA & \\
\hline \multirow[t]{2}{*}{ AF432506 } & CCTGTTCGCCTITCAGACCT & FABP4 \\
\hline & GCCAGGTGCTITGTGCTGTA & \\
\hline \multirow[t]{2}{*}{ X65459 } & GGACAGCCACAACTITGACG & FABP7 \\
\hline & GCTGCTGATGATCACTGTGG & \\
\hline \multirow[t]{2}{*}{ AJ851480 } & TGATGCAAGCACACGACTTG & ACSL1 \\
\hline & ACCCACCAGGGTATTTGTCG & \\
\hline \multirow[t]{2}{*}{ AJ720861 } & AGGTTCACCCAGATCCCAGA & LSS \\
\hline & CCACAGTCCCGTGTGCTAAA & \\
\hline \multirow[t]{2}{*}{ AJ719295 } & CTGTTTCCCGACGAGCTCAT & INSIG1 \\
\hline & GGTACAGCAGGCCAACAACA & \\
\hline \multirow[t]{2}{*}{ AJ719718 } & GGCAGTGAACGACAGCGTTA & SC4MOL \\
\hline & TAAATGGCTGCTGCAGAGGA & \\
\hline \multirow[t]{2}{*}{ U09350 } & CGAAAGCAAATGGCTGTGAA & VIP \\
\hline & TGCTTCACCTCGAAGTTTGG & \\
\hline \multirow[t]{2}{*}{ U62026 } & GAATGCTGGCACCAGGAAA & CENPF \\
\hline & TCCGGAAAGGTTCCATCATC & \\
\hline \multirow[t]{2}{*}{ M16199 } & CGCTGGTAAAGATGGGGAAT & IL8 \\
\hline & CTTGGCGTCAGCTTCACATC & \\
\hline \multirow[t]{2}{*}{ X02009 } & GATAGCGGCTGTGTGTTTCG & LTF \\
\hline & GAGGTCCCTGAGGTTGTTGC & \\
\hline \multirow[t]{2}{*}{ AJ004940 } & CTGAATTCAAGCGCAAGCAC & HSPA8 \\
\hline & TGACAGGGTACGCTTTGCAC & \\
\hline \multirow[t]{2}{*}{ AF411083 } & GTTGCTITGCTAACGCCTTG & SFTPA1 \\
\hline & AGAGCTCCCAGACCAAGCAG & \\
\hline \multirow[t]{2}{*}{ X16881 } & TTCCACGGGGACTCAGAGAT & $\mathrm{CDC} 2$ \\
\hline & TGCAAGGATTCCACATCAGG & \\
\hline \multirow[t]{2}{*}{ U12438 } & GTCAGCAGGCTGGAGGTCTT & $\mathrm{RFC2}$ \\
\hline & AGCAGAGGATGCTCCTCCTT & \\
\hline \multirow[t]{2}{*}{ Y14971 } & GGCTGTAGCTGCTGTCATGG & CXC chemokine K60 \\
\hline & TATGCACTGGCATCGGAGTT & \\
\hline \multirow[t]{2}{*}{ NM_204305 } & GGCACTGTCAAGGCTGAGAA & chGAPDH \\
\hline & TGCATCTGCCCATTTGATGT & \\
\hline
\end{tabular}

The first column indicates the NCBI accession number for designated genes, and the second column shows sequences for the forward and reverse primers. The gene symbols are provided in the third column. contains the highest number (140) of genes, while 125 genes were involved in genetic disorders, and 54 genes were grouped as inflammatory responses.

\section{Gene network analysis}

Gene network analysis, which represents the intermolecular connections among interacting genes based on functional knowledge inputs, was performed on the differentially expressed genes using IPA program (see Additional file 4). In this way, 21 possible gene networks for all days post ILTV infection were generated based on differential gene expression. Of these 21 gene networks, only 6 gene networks were identical at all time points following ILTV infection. Possibly, the reason why only 6 of 21 networks were identical might be because of differences in the sets of focus molecules which are generated from $\mathrm{p}$-values and fold change values of differential gene expression that are used in IPA algorithms. The dynamics of alterations in gene expression for a subset of genes during the time course of ILTV infection can provide insights into biologically interacting genes within a network that display functional similarities. The most interactive network (network \#1) is presented in Figure 5 whereas the other networks are shown in Additional file 5.

Network \#1 is closely associated with a signaling pathway of IL6, which is a cytokine known to be involved in cell proliferation and inflammatory responses [32]. The top functions related with genes in network \#1 involve cancer, gastrointestinal disease, and the cell cycle. Interestingly, expression of certain genes in network \#1 such as CDC20 (cell division cycle 20 homolog), PTTG1 (pituitary tumor transforming 1), $\mathrm{CDC} 2$, and Cyclin $\mathrm{B}$, which are associated with cellular proliferation in cell cycle progression, appeared to be inversely related to IL6 expression. The dynamics of alterations in gene expression over time during ILTV infection suggest that ILTV infection elevates IL6 expression followed by the inhibition of cellular proliferation. In contrast, expression patterns of HPGD (hydroxyprostaglandin dehydrogenase 15-NAD), SOCS (suppressors of cytokine signaling), JAK (Janus kinase 1), and NASP (nuclear autoantigenic sperm protein) were independent of the IL6 expression pattern (Figure 5A, B and Additional file $5 \mathrm{~A})$. JAK is known to enhance cellular proliferation through the signal transducer and activator of transcription (STAT) pathway that can be suppressed by IL6 signaling [33]. The consistent downregulation of JAK 
Table 3 Comparison of fold changes between microarray and qRT-PCR

\begin{tabular}{|c|c|c|c|c|c|c|c|c|c|}
\hline \multirow[t]{2}{*}{ Gene Accession \# } & \multirow[t]{2}{*}{ Gene Symbol } & \multicolumn{2}{|c|}{1 Day } & \multicolumn{2}{|c|}{3 Day } & \multicolumn{2}{|c|}{5 Day } & \multicolumn{2}{|c|}{7 Day } \\
\hline & & Micro-array & RT-PCR & Micro-array & RT-PCR & Micro-array & RT-PCR & Micro-array & RT-PCR \\
\hline AJ721110 & VNN2 & 0.5 & 0.3 & 3.3 & 3.5 & 6.5 & 8.7 & 2.5 & 2.6 \\
\hline AF070478 & MMP13 & 0.7 & 0.8 & 3.4 & 3.7 & 2.9 & 3.8 & 0.7 & 0.5 \\
\hline AF062392 & MMP27 & 0.8 & 0.8 & 4.1 & 7.8 & 6.6 & 23.7 & 3.5 & 7.9 \\
\hline X03509 & CKB & 0.9 & 1.4 & 4.7 & 6.8 & 5.5 & 11.0 & 2.0 & 3.3 \\
\hline AJ309540 & IL6 & 0.9 & 1.1 & 4.8 & 7.7 & 7.2 & 37.1 & 3.1 & 5.7 \\
\hline AF432506 & FABP4 & 1.0 & 1.2 & 5.3 & 7.8 & 7.1 & 33.4 & 15.0 & 10.0 \\
\hline X65459 & FABP7 & 1.1 & 1.5 & 0.3 & 0.8 & 0.8 & 1.1 & 0.2 & 0.3 \\
\hline AJ851480 & ACSL1 & 1.2 & 0.9 & 7.3 & 6.0 & 8.7 & 8.0 & 7.3 & 7.6 \\
\hline AJ720861 & LSS & 1.3 & 1.1 & 1.1 & 0.7 & 1.3 & 1.1 & 0.2 & 0.1 \\
\hline AJ719295 & Insulin induced gene 1 & 1.5 & 1.3 & 1.0 & 0.7 & 0.9 & 0.9 & 0.2 & 0.1 \\
\hline AJ719718 & SC4MOL & 1.1 & 1.7 & 0.8 & 0.9 & 1.1 & 1.3 & 0.2 & 0.2 \\
\hline U09350 & VIP & 2.0 & 2.4 & 0.2 & 0.1 & 0.3 & 0.2 & 0.2 & 0.2 \\
\hline U62026 & CENPF & 3.3 & 9.9 & 0.7 & 0.7 & 1.4 & 2.2 & 0.6 & 0.6 \\
\hline M16199 & IL8 & 3.7 & 3.0 & 22.4 & 43.4 & 26.8 & 172.7 & 18.5 & 39.0 \\
\hline X02009 & LTF & 0.7 & 0.5 & 2.7 & 2.3 & 3.6 & 5.2 & 3.2 & 4.1 \\
\hline AJ004940 & HSPA8 & 0.9 & 1.1 & 0.5 & 0.4 & 0.6 & 0.5 & 2.7 & 3.2 \\
\hline AF411083 & SFTPA1 & 1.7 & 2.5 & 0.4 & 0.7 & 0.9 & 0.9 & 0.4 & 0.3 \\
\hline X16881 & $\mathrm{CDC2}$ & 1.9 & 2.2 & 0.4 & 0.3 & 0.7 & 0.6 & 0.4 & 0.4 \\
\hline U12438 & $\mathrm{RFC2}$ & 1.9 & 2.0 & 0.8 & 0.6 & 1.0 & 0.9 & 0.3 & 0.2 \\
\hline Y14971 & CXC chemokine $\mathrm{K} 60$ & 3.7 & 7.9 & 17.3 & 60.3 & 19.7 & 206.4 & 11.3 & 38.2 \\
\hline
\end{tabular}

The gene expression levels of 20 genes at four different time points in microarray analysis were confirmed by qRT-PCR. The expression levels were presented by fold changes values in microarray analysis, while, for qRT-PCR, the values were calculated by $2^{-\Delta \Delta C T}$ method [31], which would be comparable to fold changes in the microarray. All values are mean values determined by the calculation from three replicating assays.

supports a role of JAK in the repression of cellular proliferation by ILTV infection. The top functions of genes in network \#2 are involved with cellular compromise, connective tissue disorders, and post-translational modifications. Several heat shock proteins (HSP) were also focused in this network (see Additional file 5B). Heat shock proteins, especially the HSP70 family that serve as molecular chaperones, are known to interact with viral early immediate genes in HSV-1 genomic DNA replication [34]. Interestingly, since the expression of several HSPs in network \#2 were downregulated, it is reasonable to hypothesize that the lower HSP through 5 dpi may lead to production of erroneous virion structures of ILTV that in turn results in low ILTV titers in tissue culture, which has been reported to barely exceed one infectious unit per cell $[1,35]$.

Network \#3 contains genes for growth factors and matrix metalloproteinases (MMPs), and genes have top functions associated with endocrine system function and development, carbohydrate metabolism, and digestive system function and development (see Additional file $5 \mathrm{C})$. Expression for growth factors and MMPs increased on $3 \mathrm{dpi}$ and remain elevated through $7 \mathrm{dpi}$. This observation is in agreement with other reports that infection with herpesviruses, such as HSV and HCMV, lead to an increase in growth factor expression and MMPs for extracellular remodeling, tissue invasion and angiogenesis [36-38]. Networks \#4 and \#5 contain cytokine genes (IFN $\beta$ and IL1 $\beta$ ), chemokine genes (CCL20 and CCL4), and genes of the NF-kB families (NF-kB and NFIB) with top functions that are involved in organism injury and abnormalities, antigen presentation, cell mediated immune responses, lipid metabolism, small molecule biochemistry, and molecular transport (see Additional file 5D and 5E). Finally, genes in network \#6 contain IL1, NF-kB, and ID1 that function in cardiac inflammation, cardiovascular disease and in the inflammatory response (see Additional file 5F). Interacting molecules found in networks \#4, 5, and 6 are mostly focused on the host immune responses against pathogenic infections.

The network analysis suggests that a large number of biological pathways, regulated by various sets of genes, closely interact with each other in host responsiveness during ILTV infection. More detailed interactions among genes showing altered expression levels in each network are currently under investigation to identify host-response mechanisms that may occur in conjunction with general immunological reactions during ILTV infections.

The fold changes in gene expression of key molecules associated with cellular immune response, cell signaling, MMP molecules, cytokines, chemokines, and cell proliferation were plotted individually (Figure 6). This was 


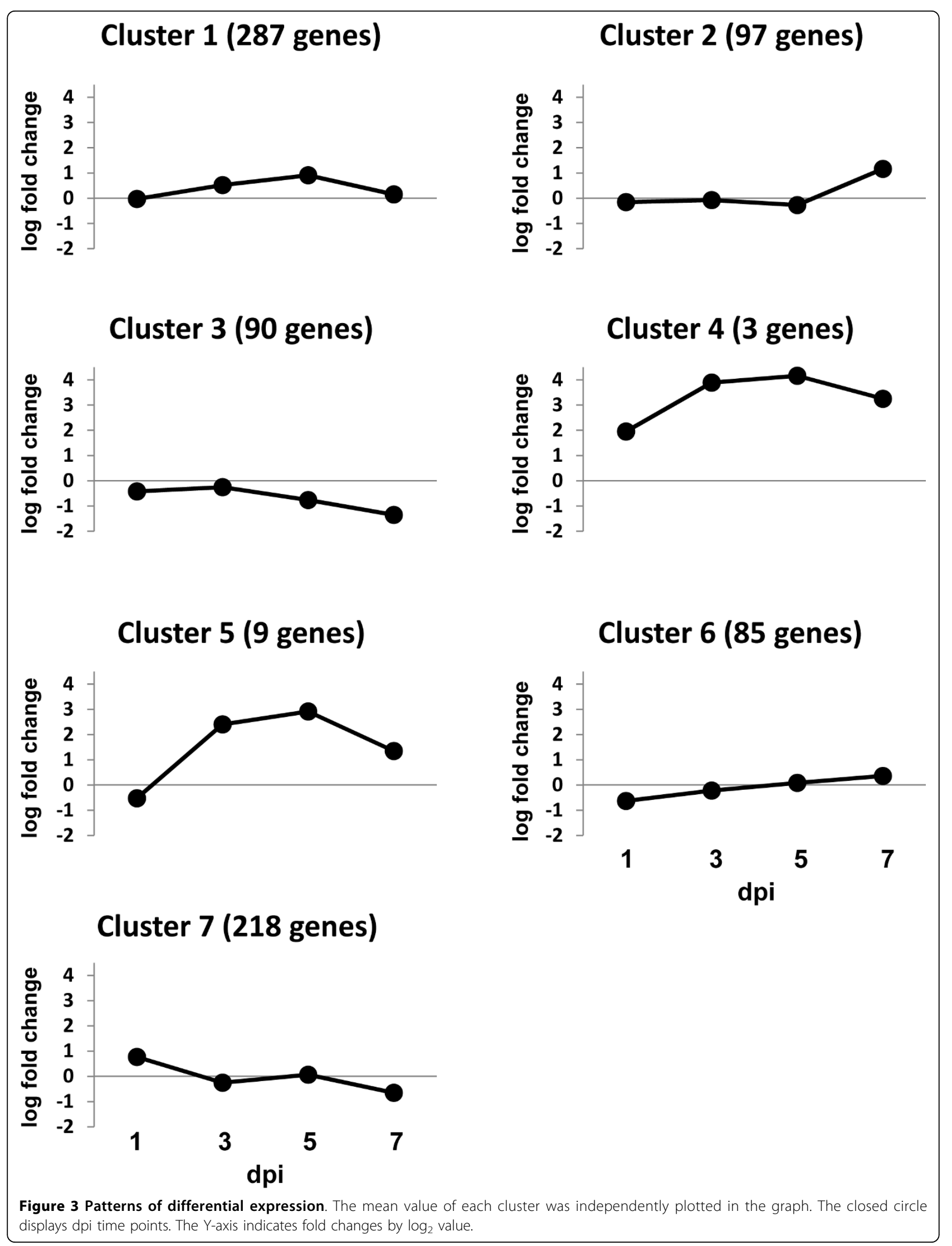




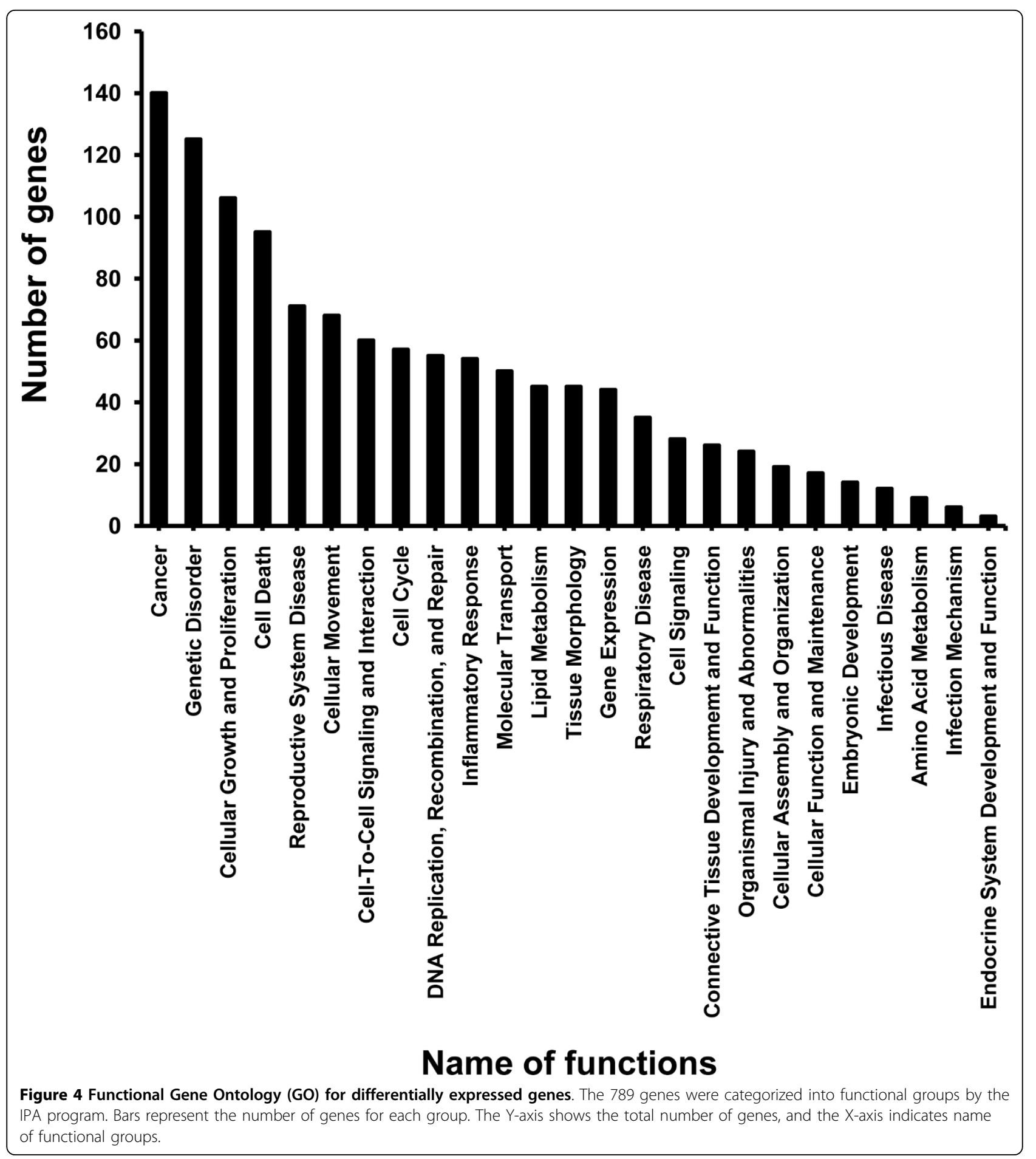

done since the molecules may help in clarifying the interaction of host lung cells with ILTV. Four matrix metalloproteinases (MMPs) including MMP 7, 13, 16, and 27 were differentially expressed during ILTV infections. For example, MMP 1, 2, and 9 were shown to function in cell invasions of primary human endothelial cell in Kaposi's sarcoma-associated herpesvirus (KSHV) pathogenesis [39]. Similarly the viral oncoprotein meq in MDV is known to activate MMP3 transcription [40]. Furthermore, the balance between MMP9 and tissue inhibitor of metalloproteinases 1 (TIMP1) was altered in human macrophages in HCMV infection, such that MMP9 activity declined in response to HCMV infection. Moreover, it was shown that HCMV infection may 


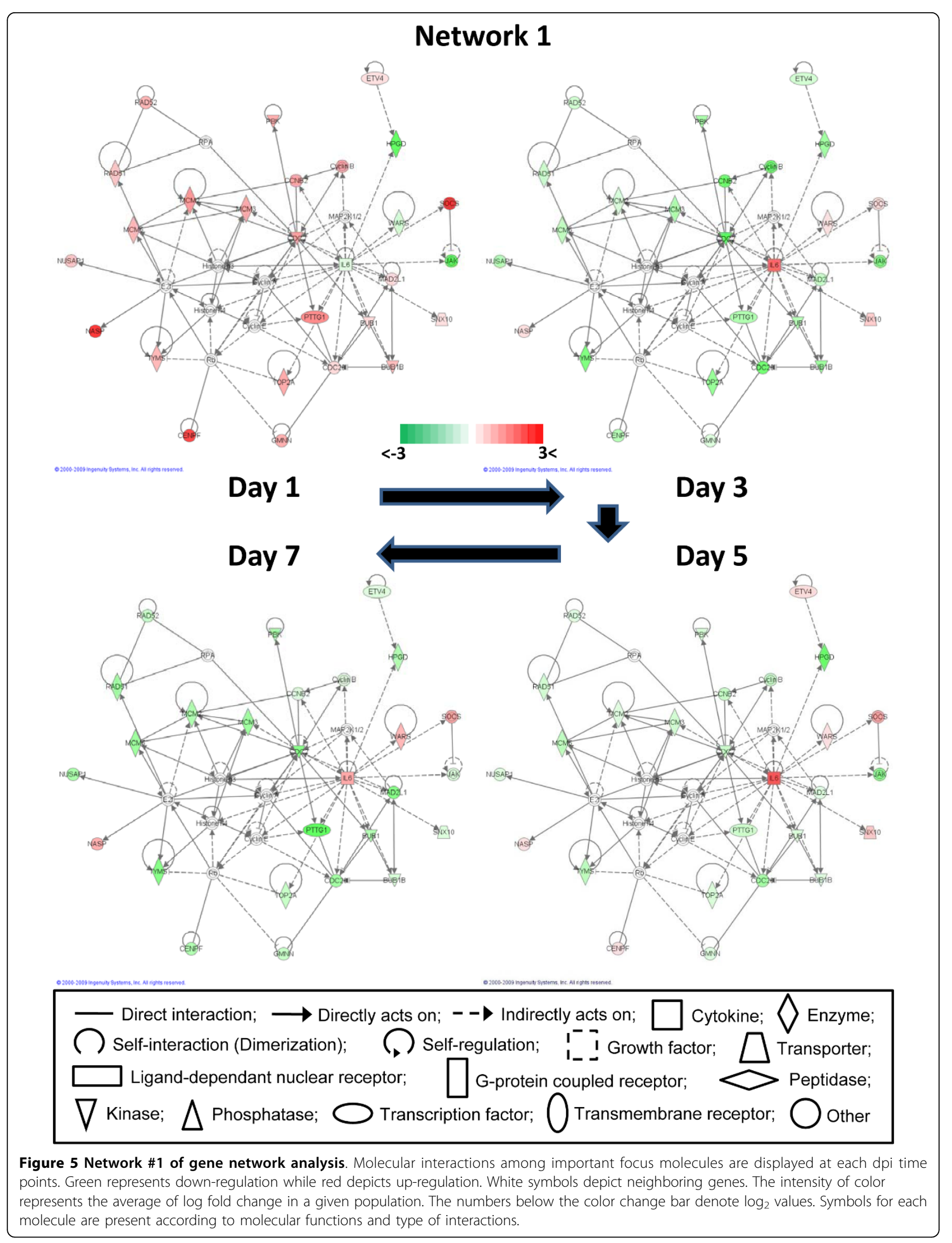




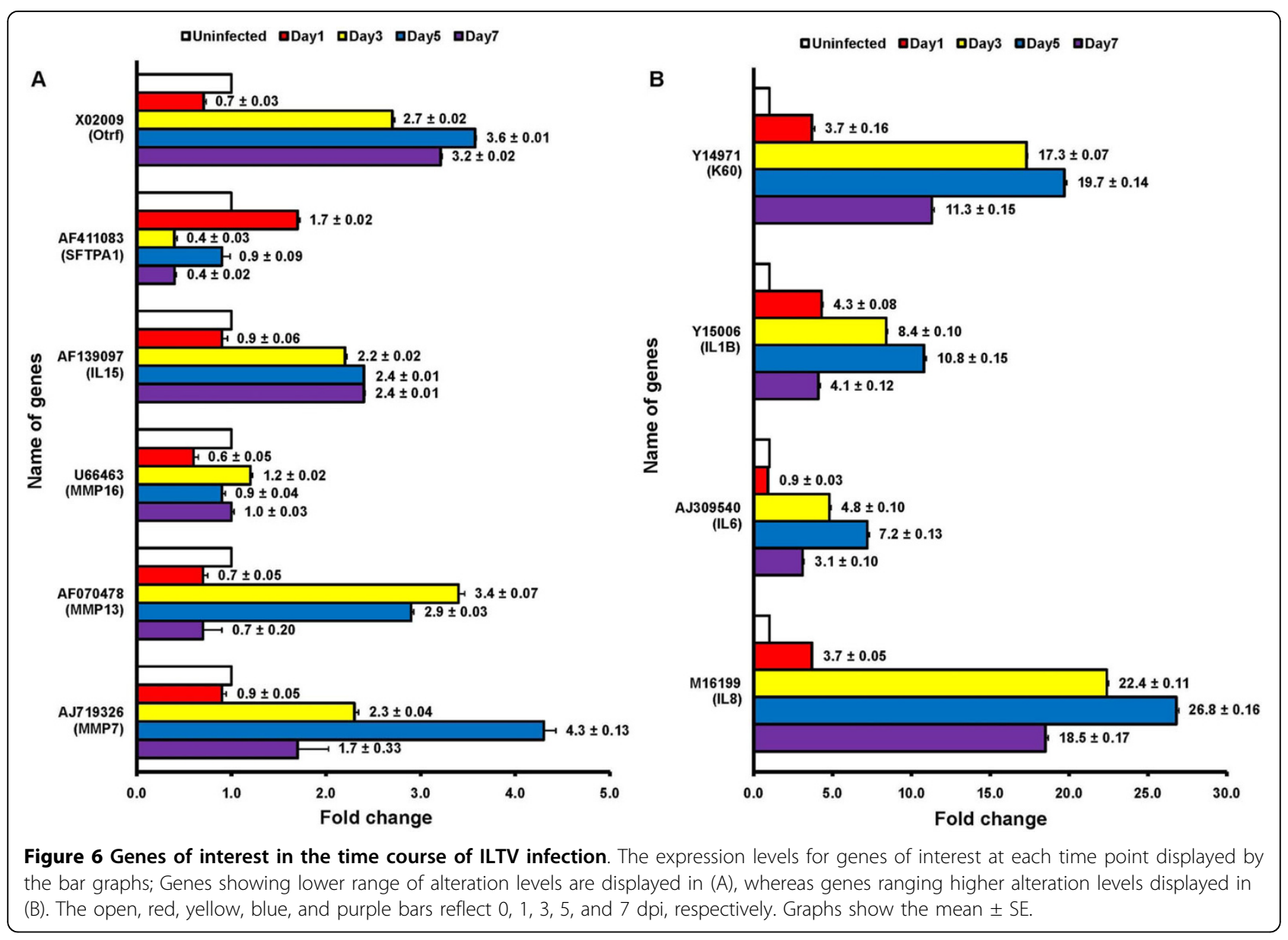

affect atherogenesis in mice through the control of MMP9 expression [38]. Taken together, these results suggest that MMPs generally play a role in herpesvirus pathogenesis, but different isoforms of MMPs may be capable of responding to specific herpesviruses. Furthermore, in the present study with chicken lung cells, expression of surfactant protein A (SFTPA-1; GenBank accession - AF411083; Table 1 and 3) was downregulated by ILTV infection. Since the SFTPA-1 is a transcriptional indicator of EGFR (epidermal growth hormone receptor) signaling pathway [41], the reduction in SFTPA-1 expression suggests that the EGFR signaling pathway is suppressed by ILTV infection. This conclusion is consistent with the reported downregulation of EGFR functions in HCMV infected human lung [41] and foreskin fibroblastic cells [42]. Additionally, our findings are similar to a report in which the mRNA expression of SFTPA-1 declined after inoculation of influenza A virus H9N2 into chicken lung cells [43].

Another molecule, ovotransferrin (Otrf; GenBank accession-X02009; Table 1 and 3) has both iron transport- and antibacterial-activities. In the present study, the expression level of Otrf increased in ILTV infected cells (Figure 6A). The finding is qualitatively similar to a possible role of Otrf in MDV infection that might protect the spread of MDV in chicken embryonic fibroblast cells [44]. Otrf also was found to accelerate the expression of immune response gene such as IFN $-\gamma$ against MDV infection [45]. Furthermore, lactoferrin, which is a homologous form of transferrin in mammals, showed antiviral activity against canine herpesvirus [46]. It has been hypothesized that the anti-viral activity of Otrf may be similar to the anti-HSV capability of mammalian transferrins [47]. IL6 plays a role in both pro-inflammatory and anti-inflammatory responses [32]. The elevation of IL6 expression during virus infection has been wellcharacterized as one of the immune response activities in the pathogenesis of various viruses, such as Dengue virus in human [48], or HSV-1 in mice [49]. Also, the expression of IL6 is increased by KHSV-encoding miRNA [50]. Similarly, expression of IL8 and IL1 $\beta$ were upregulated in ILTV infected cells and also in MDV infected chicken lung [51]. These observations are consistent with previous findings of NF-kB activation via 
IL8 signaling pathway by human herpesvirus (HHV)-8 infection [52] and HHV-6 infection in peripheral blood mononuclear cell cultures [53], respectively.

In addition to the well-characterized host-virus interactions, a variety of unique responses detected with the microarray analysis of ILTV infection in the present study. For instance, the expression level of vasoactive intestinal peptide (VIP; GenBank accession numberU09350: Table 1 and 3) decreased dramatically in ILTV infection, but the functional consequences were not determined. Likewise, genes related to various metabolic enzyme functions such as acyl-CoA synthetase long chain-1 (ACSL1; GenBank Accession number-AJ851480; Table 1 and 3) were differentially expressed in ILTV infected cells, but the precise mechanisms in the host response have not been verified. Therefore, further investigations are being performed to identify unique and more deeply involved interactions between host lung cells and ILTV.

\section{Conclusions}

In this study, we have demonstrated changes in global gene expression in response to ILTV infection in chicken embryo lung cells using microarray analysis. A total of 789 differentially expressed genes were involved in a variety of molecular and cellular defense mechanisms of immune response, cell cycle regulation, cellular metabolism, and matrix metalloprotenases. Moreover, the bioinformatics studies, such as gene ontology and gene network analysis, using knowledge based bioinformatics tools (Ingenuity Pathway Analysis and DAVID) revealed biological functionalities and intermolecular connections among interacting genes associated with differentially expressed genes. Our study provides epigenetic insights into the pathogenesis of ILTV infection in chicken lung cells.

\section{Methods}

\section{Cell culture and ILTV infection}

Cell culture reagents were purchased from Invitrogen Life Technologies (Carlsbad, CA, USA). Chicken embryo lungs were isolated from 19 day old specific-pathogen free (SPF) chicken embryos (Charles River Laboratories, North Franklin, CT, USA). Lung tissues were homogenized and incubated in a $0.125 \%$ trypsin solution for 30 min at room temperature $\left(25^{\circ} \mathrm{C}\right)$. Cells dissociated from lung tissues were suspended in a 1:1 ratio of mammary epithelial growth media (MEGM; Lonza, Rockland, ME, USA) and Dulbecco's Modified Eagle's Medium (DMEM, $0.45 \%$ glucose) plus $2 \%$ fetal bovine serum (FBS), 100 units $/ \mathrm{ml}$ penicillin, $100 \mu \mathrm{g} / \mathrm{ml}$ streptomycin, and $2 \mathrm{mM}$ L-glutamine in $10 \mathrm{~cm}$ tissue culture dishes (Sarstedt Inc., Newton, NC, USA) pretreated with $0.5 \%$ gelatin in PBS to improve cell adhesion. Cultured cells were grown at $39^{\circ} \mathrm{C}$ containing $5 \% \mathrm{CO}_{2}$ until cells reached confluent monolayers ( 2 to 4 days). The USDA reference strain of ILTV (National Veterinary Services Laboratories, Ames, IA, USA) was used to infect the chicken embryonic lung cells at a multiplicity of infection (m.o.i.) of 0.1. Infected cells were incubated at $37^{\circ} \mathrm{C}$ for $1 \mathrm{hr}$ with rocking gently every $15 \mathrm{~min}$. After the incubation, $10 \mathrm{ml}$ of media, 1:1 MEGM/DMEM, were added to each culture dish, and the cells were incubated at $37^{\circ} \mathrm{C}$ in $5 \% \mathrm{CO}_{2}$ for up to 7 days. This research was performed under the permitted protocol approved by both the Institutional Biosafety Committee (IBC; permit number: 10007) of University of Arkansas and the Animal and Plant Health Inspection Service (APHIS; permit number: 102743) of United States Department of Agriculture (USDA).

\section{Total RNA extraction}

Total RNA was extracted from uninfected- or ILTV infected chicken embryonic lung cells at 1, 3, 5, and 7 dpi using TRIzol reagent (Invitrogen Life Technologies, Carlsbad, CA, USA) following the manufacturer's instructions. Total RNA was treated with DNase I (New England BioLabs Inc., Ipswich, MA, USA), and RNA was re-purified by the TRIzol reagent. The quality of RNA was checked by fractionation on an agarose gel (data not shown).

\section{Probe labeling and microarray hybridization}

A two color labeling microarray system was used to compare uninfected-and ILTV infected embryonic lung cells at $1,3,5$, and $7 \mathrm{dpi}$. Fluorescently labeled complementary RNA (cRNA) probes were generated by using the Two Color Microarray Quick Labeling kit (Agilent Technologies, Palo Alto, CA, USA) and following the manufacturer's instructions. RNA spike-in controls were used to adjust possible dye effects following manufacturer's instructions. The Spike-in controls represent two sets of ten synthesized RNA mixtures derived from the Adenovirus E1A transcriptome with different concentrations in each set [29]. These spike-in sets were mixed with either uninfected control or infected samples and co-hybridized to arrays. Briefly, $2 \mu \mathrm{g}$ of total RNA were mixed with Spike-ins and converted to cDNA using reverse transcriptase and oligo dT primers in which T7 promoter sequences were added. T7 RNA polymerase was used for the synthesis and labeling of cRNA with either Cy3 dye for the uninfected control or Cy5 dye for the ILTV infected samples. The fluorescently labeled cRNA probes were purified using the Qiagen RNeasy Mini Kit (Qiagen Inc., Valencia, CA, USA), and the concentration, fluorescent intensities, and quality of labeled cRNA probes were determined using a Nano-drop spectrophotometer (Thermo Scientific, Wilmington, DE, USA). An equal amount (825 ng) of Cy3 and Cy5 labeled cRNA probes were hybridized on a $4 \times 44 \mathrm{~K}$ Agilent custom chicken oligo microarray 
(array ID: 017698). The hybridized slides were washed using a commercial kit package (Agilent Technologies, Palo Alto, CA, USA) and then scanned using a Genepix 4000B scanner (Molecular Devices Corporation, Sunnyvale, CA, USA) with the tolerance of saturation setting of $0.005 \%$. Three biological replicates were conducted.

\section{Microarray data collection and analysis}

Background-corrected red and green intensities for each spot were used in the subsequent analysis. Global normalization based on local polynomial regression (loess) was applied to the intensities to remove effects that were due to undesirable systematic variations in microarray experiments rather than biological differences. The average values of the resulting normalized expression values in replicate hybridization sets were considered in the subsequent analysis. In order to identify a given set of genes that exhibited major alterations over time, a model-based clustering method [30] was employed, and the genes in the cluster were considered as differentially expressed over the time period. All analytic techniques were implemented in R (http://www.R-project.org).

\section{Quantitative reverse transcription-polymerase chain reaction (qRT-PCR)}

Reverse transcription was performed with $3 \mu \mathrm{g}$ of total RNA using Superscript II reverse transcriptase (Invitrogen Life Technologies, Carlsbad, CA, USA) with oligo $\mathrm{dT}_{12-18}$ primers (Invitrogen Life Technologies, Carlsbad, CA, USA) following the manufacturer's instructions. The reverse-transcribed cDNA were diluted by $1: 10$ ratio and a portion $(1 \mu \mathrm{l})$ of each product was subjected to qPCR under the following conditions: 40 cycles of $95^{\circ} \mathrm{C}$ for $30 \mathrm{~s}$, gene-specific annealing temperature for $62^{\circ} \mathrm{C}$ for $1 \mathrm{~min}$, extension for $30 \mathrm{~s}$ at $72^{\circ} \mathrm{C}$, and a final extension at $72^{\circ} \mathrm{C}$ for $10 \mathrm{~min}$. A non-template control and endogenous control (chicken GAPDH) were used for the relative quantification. The differential expression levels for the ILTV infected group were compared by the $2^{-\triangle \Delta C T}$ method against the uninfected controls [31]. Primers for qRT-PCR were designed using Primer3 software (http://frodo.wi.mit.edu/cgi-bin/primer3/primer3.cgi) with these parameters: amplicon length, 95$100 \mathrm{bp}$; primer length, 18-27 nucleotides; primer melting temperature, $60-64^{\circ} \mathrm{C}$; primer and amplicon GC content, 20-80\%; difference in melting temperature between forward and reverse primers, $1-2^{\circ} \mathrm{C}$. Primers were synthesized by Integrated DNA Technologies (Coralville, IA, USA). Primer information is listed in Table 2.

\section{Bioinformatics}

Functional interpretation of differentially expressed genes was analyzed in the context of gene ontology and molecular networks using the Ingenuity Pathways Analysis (IPA)
6.5 software (Ingenuity Systems ${ }^{\circledR}$; http://www.ingenuity. com). The differentially expressed genes were categorized, compared to genetic categories in the IPA database, and ranked according to p-values [54]. The IPA analysis determined the subcategories within each category which is supplied with an appropriate p-value and the number of genes identified. Since the size of the created network could potentially be enormous, the IPA software limited the number of molecules in the network to 35 , leaving only the most important ones based on the number of connections for each focus gene (focus genes = a subset of uploaded significant genes having direct interactions with other genes in the database) to other significant genes [55].

\section{Additional material}

\section{Additional file 1: List of $\mathbf{7 8 9}$ highly variable genes expressed} differentially. The values at each time point indicate fold changes. The black letters indicate characterized genes, the orange letters are predicted genes, and the green letters denote uncharacterized genes. The accession numbers and descriptions were derived from Agilent gene list and GenBank database.

Additional file 2: GenBank accession numbers of 7 clusters for expression patterns.

Additional file 3: Gene Ontology generated by IPA. The 789 differentially expressed genes were divided into 65 groups based on their functions.

Additional file 4: Gene lists of each network. Gene symbols and GenBank accession numbers were displayed for the illustrations of network analysis. Only focus molecules, which were elected as differentially expressed genes from microarray analysis, are marked as bold and GenBank accession numbers are provided. Accession numbers for reference molecules were not included in the table.

Additional file 5: Six gene networks. (A) network \#1 (B) network \#2 (C) network \#3 (D) network \#4 (E) network \#5 and (F) network \#6 are displayed. Enlarged images are followed by small alphabetical orders (a d) to indicate dpi time points. Colored shapes indicate focus molecules, which were identified as differentially expressed genes by microarray analysis, while clear shapes indicate reference molecules. The green represents down-regulation and the red represents up-regulation. Degree of color intensities indicates levels of fold changes.

\section{Acknowledgements}

We thank Drs. Gisela Erf (University of Arkansas) and Douglas Foster (University of Minnesota) for helpful comments and reviewing this manuscript. This work was supported, in part, by Arkansas Agricultural Experimental Station and US Poultry and Egg Association (project \#640).

\section{Author details}

'Department of Poultry Science, University of Arkansas, Fayetteville, AR 72701, USA. ${ }^{2}$ Cell and Molecular Biology Graduate Program, University of Arkansas, Fayetteville, AR 72701, USA. ${ }^{3}$ Department of Mathematical Sciences, University of Arkansas, Fayetteville, AR 72701, USA. ${ }^{4}$ Department of Poultry Science, Texas A\&M University, College Station, TX 77845, USA.

\section{Authors' contributions}

$J Y L$ and BWK designed the experiments, performed the experiments, analyzed the data, and wrote the manuscript. JJS contributed in statistical analysis of microarray data, and AW participated in virus preparation and helped analysis of the qRT-PCR data. XL and HZ contributed the analysis of microarray data. WB contributed the bioinformatics analysis and manuscript editing. All authors read and approved the final manuscript. 
Received: 13 February 2010 Accepted: 21 July 2010

Published: 21 July 2010

\section{References}

1. Fuchs W, Veits J, Helferich D, Granzow H, Teifke JP, Mettenleiter TC: Molecular biology of avian infectious laryngotracheitis virus. Vet Res 2007, 38(2):261-279.

2. Thureen DR, Keeler CL Jr: Psittacid herpesvirus 1 and infectious laryngotracheitis virus: Comparative genome sequence analysis of two avian alphaherpesviruses. J Virol 2006, 80(16):7863-7872.

3. Roizmann B, Desrosiers RC, Fleckenstein B, Lopez C, Minson AC, Studdert MJ: The family Herpesviridae: an update. The Herpesvirus Study Group of the International Committee on Taxonomy of Viruses. Arch Virol 1992, 123(3-4):425-449

4. Bagust TJ, Johnson MA: Avian infectious laryngotracheitis: virus-host interactions in relation to prospects for eradication. Avian Pathol 1995, 24(3):373-391.

5. Clarke JK, Robertson GM, Purcell DA: Spray vaccination of chickens using infectious laryngotracheitis virus. Aust Vet J 1980, 56(9):424-428.

6. Guy JS, Barnes HJ, Smith L: Increased virulence of modified-live infectious laryngotracheitis vaccine virus following bird-to-bird passage. Avian Dis 1991, 35(2):348-355

7. Kulesh DA, Clive DR, Zarlenga DS, Greene JJ: Identification of interferonmodulated proliferation-related CDNA sequences. Proc Natl Acad Sci USA 1987, 84(23):8453-8457.

8. Carter KL, Cahir-McFarland E, Kieff E: Epstein-barr virus-induced changes in B-lymphocyte gene expression. J Virol 2002, 76(20):10427-10436.

9. Malizia AP, Keating DT, Smith SM, Walls D, Doran PP, Egan JJ: Alveolar epithelial cell injury with Epstein-Barr virus upregulates TGFbeta1 expression. Am J Physiol Lung Cell Mol Physiol 2008, 295(3):451-460.

10. Chen X, Liang S, Zheng W, Liao Z, Shang T, Ma W: Meta-analysis of nasopharyngeal carcinoma microarray data explores mechanism of EBVregulated neoplastic transformation. BMC Genomics 2008, 9:322-332.

11. Jones JO, Arvin AM: Microarray analysis of host cell gene transcription in response to varicella-zoster virus infection of human $T$ cells and fibroblasts in vitro and SCIDhu skin xenografts in vivo. J Virol 2003, 77(2):1268-1280

12. Chan G, Bivins-Smith ER, Smith MS, Smith PM, Yurochko AD: Transcriptome analysis reveals human cytomegalovirus reprograms monocyte differentiation toward an M1 macrophage. J Immunol 2008, 181(1):698-711.

13. Liu HC, Cheng HH, Tirunagaru V, Sofer L, Burnside J: A strategy to identify positional candidate genes conferring Marek's disease resistance by integrating DNA microarrays and genetic mapping. Anim Genet 2001, 32(6):351-359.

14. Morgan RW, Sofer L, Anderson AS, Bernberg EL, Cui J, Burnside J: Induction of host gene expression following infection of chicken embryo fibroblasts with oncogenic Marek's disease virus. J Virol 2001, 75(1):533-539.

15. Sarson AJ, Abdul-Careem MF, Zhou H, Sharif S: Transcriptional analysis of host responses to Marek's disease viral infection. Viral Immunol 2006, 19(4):747-758.

16. Sarson AJ, Parvizi P, Lepp D, Quinton M, Sharif S: Transcriptional analysis of host responses to Marek's disease virus infection in genetically resistant and susceptible chickens. Anim Genet 2008, 39(3):232-240.

17. Heidari M, Huebner M, Kireev D, Silva RF: Transcriptional profiling of Marek's disease virus genes during cytolytic and latent infection. Virus Genes 2008, 36(2):383-392.

18. Karaca G, Anobile J, Downs D, Burnside J, Schmidt CJ: Herpesvirus of turkeys: microarray analysis of host gene responses to infection. Virology 2004, 318(1):102-111.

19. Mossman KL, Macgregor PF, Rozmus JJ, Goryachev AB, Edwards AM, Smiley JR: Herpes simplex virus triggers and then disarms a host antiviral response. J Virol 2001, 75(2):750-758.

20. Clement C, Popp MP, Bloom DC, Schultz G, Liu L, Neumann DM, Bhattacharjee PS, Hill JM: Microarray analysis of host gene expression for comparison between naive and HSV-1 latent rabbit trigeminal ganglia. Mol Vis 2008, 14:1209-1221

21. Otsuka M, Aizaki H, Kato N, Suzuki T, Miyamura T, Omata M, Seki N: Differential cellular gene expression induced by hepatitis $B$ and $C$ viruses. Biochem Biophys Res Commun 2003, 300(2):443-447.
22. de la Fuente C, Santiago F, Deng L, Eadie C, Zilberman I, Kehn K, Maddukuri A, Baylor S, Wu K, Lee CG, Pumfery A, Kashanchi F: Gene expression profile of HIV-1 Tat expressing cells: a close interplay between proliferative and differentiation signals. BMC Biochem 2002, 3:14-35.

23. Geiss GK, Bumgarner RE, An MC, Agy MB, van't Wout AB, Hammersmark E, Carter VS, Upchurch D, Mullins Jl, Katze MG: Large-scale monitoring of host cell gene expression during HIV-1 infection using CDNA microarrays. Virology 2000, 266(1):8-16.

24. Sun Y, Huang PL, Li JJ, Huang YQ, Zhang L, Huang PL, Lee-Huang S: AntiHIV agent MAP30 modulates the expression profile of viral and cellular genes for proliferation and apoptosis in AIDS-related lymphoma cells infected with Kaposi's sarcoma-associated virus. Biochem Biophys Res Commun 2001, 287(4):983-994.

25. van't Wout AB, Lehrman GK, Mikheeva SA, O'Keeffe GC, Katze MG, Bumgarner RE, Geiss GK, Mullins Jl: Cellular gene expression upon human immunodeficiency virus type 1 infection of CD4(+)-T-cell lines. J Virol 2003, 77(2):1392-1402.

26. Taylor LA, Carthy CM, Yang D, Saad K, Wong D, Schreiner G, Stanton LW, McManus BM: Host gene regulation during coxsackievirus $B 3$ infection in mice: assessment by microarrays. Circ Res 2000, 87(4):328-334.

27. Li X, Chiang HI, Zhu J, Dowd SE, Zhou H: Characterization of a newly developed chicken 44 K Agilent microarray. BMC Genomics 2008, 9:60-73.

28. Mazzatti DJ, White A, Forsey RJ, Powell JR, Pawelec G: Gene expression changes in long-term culture of T-cell clones: genomic effects of chronic antigenic stress in aging and immunosenescence. Aging Cell 2007, 6(2):155-163.

29. Zahurak M, Parmigiani G, Yu W, Scharpf RB, Berman D, Schaeffer E, Shabbeer S, Cope L: Pre-processing Agilent microarray data. BMC Bioinformatics 2007, 8:142-154.

30. Fraley C, Raftery E: Model-Based Clustering, Discriminant Analysis, and Density Estimation. Journal of the American Statistical Association 2002, 97(458):611-631

31. Livak KJ, Schmittgen TD: Analysis of relative gene expression data using real-time quantitative PCR and the 2(-Delta Delta C(T)) Method. Methods 2001, 25(4):402-408.

32. Kishimoto T: Interleukin-6: from basic science to medicine-40 years in immunology. Annu Rev Immunol 2005, 23:1-21.

33. Heinrich PC, Behrmann I, Muller-Newen G, Schaper F, Graeve L: Interleukin6-type cytokine signaling through the gp130/Jak/STAT pathway. Biochem J 1998, 334(Pt 2):297-314.

34. Li L, Johnson LA, Dai-Ju JQ, Sandri-Goldin RM: Hsc70 focus formation at the periphery of HSV-1 transcription sites requires ICP27. PLOS One 2008, 3(1):e1491

35. Granzow H, Klupp BG, Fuchs W, Veits J, Osterrieder N, Mettenleiter TC: Egress of alphaherpesviruses: comparative ultrastructural study. J Virol 2001, 75(8):3675-3684.

36. Hayashi K, Hooper LC, Detrick B, Hooks JJ: HSV immune complex (HSVIgG: IC) and HSV-DNA elicit the production of angiogenic factor VEGF and MMP-9. Arch Virol 2009, 154(2):219-226.

37. Mahller YY, Vaikunth SS, Ripberger MC, Baird WH, Saeki Y, Cancelas JA, Crombleholme TM, Cripe TP: Tissue inhibitor of metalloproteinase-3 via oncolytic herpesvirus inhibits tumor growth and vascular progenitors. Cancer Res 2008, 68(4):1170-1179.

38. Straat K, de Klark R, Gredmark-Russ S, Eriksson P, Soderberg-Naucler C: Infection with human cytomegalovirus alters the MMP-9/TIMP-1 balance in human macrophages. J Virol 2009, 83(2):830-835.

39. Qian LW, Xie J, Ye F, Gao SJ: Kaposi's sarcoma-associated herpesvirus infection promotes invasion of primary human umbilical vein endothelial cells by inducing matrix metalloproteinases. J Virol 2007, 81(13):7001-7010.

40. Ajithdoss DK, Reddy SM, Suchodolski PF, Lee LF, Kung HJ, Lupiani B: In vitro characterization of the Meq proteins of Marek's disease virus vaccine strain CVI988. Virus Res 2009, 142(1-2):57-67.

41. Fairley JA, Baillie J, Bain $\mathrm{M}$, Sinclair JH: Human cytomegalovirus infection inhibits epidermal growth factor (EGF) signalling by targeting EGF receptors. J Gen Virol 2002, 83(11):2803-2810.

42. Jafferji I, Bain M, King C, Sinclair JH: Inhibition of epidermal growth factor receptor (EGFR) expression by human cytomegalovirus correlates with an increase in the expression and binding of Wilms' Tumour 1 protein to the EGFR promoter. J Gen Virol 2009, 90(7):1569-1574. 
43. Reemers SS, Veldhuizen EJ, Fleming C, van Haarlem DA, Haagsman $H$, Vervelde L: Transcriptional expression levels of chicken collectins are affected by avian influenza A virus inoculation. Vet Microbiol 2010, 141(34):379-384.

44. Giansanti F, Giardi MF, Massucci MT, Botti D, Antonini G: Ovotransferrin expression and release by chicken cell lines infected with Marek's disease virus. Biochem Cell Biol 2007, 85(1):150-155.

45. Federica Giardi M, La Torre C, Giansanti F, Botti D: Effects of transferrins and cytokines on nitric oxide production by an avian lymphoblastoid cell line infected with Marek's disease virus. Antiviral Res 2009, 81(3):248-252.

46. Tanaka T, Nakatani S, Xuan X, Kumura H, Igarashi I, Shimazaki K: Antiviral activity of lactoferrin against canine herpesvirus. Antiviral Res 2003, 60(3):193-199.

47. Jenssen $\mathrm{H}$ : Anti herpes simplex virus activity of lactoferrin/lactoferricin an example of antiviral activity of antimicrobial protein/peptide. Cell Mol Life Sci 2005, 62(24):3002-3013.

48. Lee YR, Su CY, Chow NH, Lai WW, Lei HY, Chang CL, Chang TY, Chen SH, Lin YS, Yeh TM, Liu HS: Dengue viruses can infect human primary lung epithelia as well as lung carcinoma cells, and can also induce the secretion of IL-6 and RANTES. Virus Res 2007, 126(1-2):216-225.

49. LeBlanc RA, Pesnicak L, Cabral ES, Godleski M, Straus SE: Lack of interleukin-6 (IL-6) enhances susceptibility to infection but does not alter latency or reactivation of herpes simplex virus type 1 in IL-6 knockout mice. J Virol 1999, 73(10):8145-8151.

50. Qin Z, Kearney P, Plaisance K, Parsons CH: Pivotal advance: Kaposi's sarcoma-associated herpesvirus (KSHV)-encoded microRNA specifically induce IL- 6 and IL-10 secretion by macrophages and monocytes. J Leukoc Biol 2010, 87(1):25-34.

51. Abdul-Careem MF, Haq K, Shanmuganathan S, Read LR, Schat KA, Heidari M, Sharif S: Induction of innate host responses in the lungs of chickens following infection with a very virulent strain of Marek's disease virus. Virology 2009, 393(2):250-257.

52. Sun Q, Matta H, Lu G, Chaudhary PM: Induction of IL-8 expression by human herpesvirus 8 encoded vFLIP K13 via NF-kappaB activation. Oncogene 2006, 25(19):2717-2726.

53. Flamand L, Gosselin J, D'Addario M, Hiscott J, Ablashi DV, Gallo RC, Menezes J: Human herpesvirus 6 induces interleukin- 1 beta and tumor necrosis factor alpha, but not interleukin-6, in peripheral blood mononuclear cell cultures. J Virol 1991, 65(9):5105-5110.

54. Mori R, Xiong S, Wang Q, Tarabolous C, Shimada H, Panteris E, Danenberg KD, Danenberg PV, Pinski JK: Gene profiling and pathway analysis of neuroendocrine transdifferentiated prostate cancer cells. Prostate 2009, 69(1):12-23.

55. Calvano SE, Xiao W, Richards DR, Felciano RM, Baker HV, Cho RJ, Chen RO, Brownstein BH, Cobb JP, Tschoeke SK, Miller-Graziano C, Moldawer LL, Mindrinos MN, Davis RW, Tompkins RG, Lowry SF: A network-based analysis of systemic inflammation in humans. Nature 2005, 437(7061):1032-1037.

doi:10.1186/1471-2164-11-445

Cite this article as: Lee et al:: Transcriptional profiling of host gene expression in chicken embryo lung cells infected with laryngotracheitis virus. BMC Genomics 2010 11:445.

\section{Submit your next manuscript to BioMed Central and take full advantage of:}

- Convenient online submission

- Thorough peer review

- No space constraints or color figure charges

- Immediate publication on acceptance

- Inclusion in PubMed, CAS, Scopus and Google Scholar

- Research which is freely available for redistribution

Submit your manuscript at www.biomedcentral.com/submit
Biomed Central 